- FINANSE I PRAWO FINANSOWE.

- Journal of Finance and Financial Law •

Marzec/March 2019 • vol. 1(21): 11-26

http://dx.doi.org/10.18778/2391-6478.1.21.02

\title{
FUNKCJONOWANIE MODELU SPRZEDAŻOWEGO EQUITY RELEASE W POLSCE
}

Przemysław Buzałek

Wydział Ekonomiczno-Socjologiczny, Uniwersytet Łódzki

\section{Streszczenie}

Artykuł traktuje o funkcjonowaniu modelu sprzedażowego equity release w Polsce. Wskazane są w nim podstawowe różnice między odwróconym kredytem hipotecznym a świadczeniami dożywotnimi, scharakteryzowane są umowy, w ramach których zawierane są świadczenia dożywotnie, opisana jest sytuacja na rynku w latach 2010-2017, a także zidentyfikowane są podstawowe problemy wynikające $z$ braku odrębnych regulacji prawnych.

Słowa kluczowe: świadczenia dożywotnie, renta dożywotnia, umowa dożywocia, odwrócony kredyt hipoteczny, fundusze hipoteczne.

JEL Class: J14. 


\section{WPROWADZENIE}

Odpowiedzią na postępujący proces starzenia się ludności, stopniowe osłabianie więzi rodzinnych i niekorzystną sytuację ekonomiczną osób starszych po przejściu na emeryturę może rozwój usług equity release. Wyróżnia się dwa modele tego produktu finansowego - kredytowy i sprzedażowy. W pierwszym przypadku mówimy o odwróconym kredycie hipotecznym, a w drugim - o świadczeniach dożywotnich. W niniejszej publikacji przybliżone zostanie funkcjonowanie modelu sprzedażowego equity release $\mathrm{w}$ Polsce. Autor dostrzegł potrzebę zagłębienia się $\mathrm{w}$ tę tematykę $\mathrm{z}$ uwagi na to, że polski rynek equity release w modelu sprzedażowym funkcjonuje obecnie bez odrębnych regulacji i dochodzą z niego niepokojące sygnały o nadużyciach.

Celem artykułu jest przedstawienie funkcjonowania modelu sprzedażowego equity release $\mathrm{w}$ Polsce. Autor sprawdza m.in. na jakich zasadach oferowane są przez fundusze hipoteczne świadczenia dożywotnie i poszukuje odpowiedzi czy obowiązujące rozwiązania prawne zabezpieczają interesy seniorów w odpowiedni sposób.

\section{1. ŚWIADCZENIA DOŻYWOTNIE A ODWRÓCONY KREDYT HIPOTECZNY}

Model sprzedażowy equity release to proces, w którym właściciel nieruchomości przenosi na świadczeniodawcę prawo własności do całości bądź części nieruchomości w zamian za wypłatę świadczeń pieniężnych (zwykle realizowanych dożywotnio) oraz możliwość zamieszkiwania w tej nieruchomości do śmierci. Oznacza to, że beneficjent już w momencie zawarcia umowy przenosi na świadczeniodawcę własność nieruchomości (ewentualnie prawo użytkowania wieczystego lub spółdzielcze własnościowe prawo do lokalu bądź domu w spółdzielni mieszkaniowej). Z uwagi na brak odrębnych uregulowań prawnych rozwiązania wykorzystywane w modelu sprzedażowym aktualnie bazują na przepisach kodeksu cywilnego, które pozwalają, aby stroną zobowiązaną do udzielania świadczeń dożywotnich była nie tylko osoba fizyczna, ale również osoba prawna. Fakt ten wykorzystują instytucje, zwane funduszami hipotecznymi, oferujące świadczenia dożywotnie na warunkach komercyjnych. Co warte podkreślenia, mimo używania nazwy „fundusz hipoteczny”, podmioty te nie podlegają ustawie o funduszach inwestycyjnych i nie są rejestrowane w rejestrze funduszy. Ponadto, nie podlegają kontroli Komisji Nadzoru Finansowego i nie mają obowiązku ujawniać publicznie swoich wyników finansowych (wyjątkiem jest Fundusz Hipoteczny DOM S.A., którego akcje znajdują się w obrocie publicznym) [Willmann 2016:156-157; Lewicka 2015: 99-101]. 
Tabela 1. Podstawowe różnice między odwróconym kredytem hipotecznym a świadczeniem dożywotnim

\begin{tabular}{|c|c|c|}
\hline Cecha & Odwrócony kredyt hipoteczny & Świadczenie dożywotnie \\
\hline $\begin{array}{l}\text { Prawo do nierucho- } \\
\text { mości }\end{array}$ & $\begin{array}{l}\text { Przechodzi na bank po śmierci } \\
\text { właściciela, spadkobiercy mają } \\
\text { prawo do spłaty tego kredytu do } \\
12 \text { miesięcy po śmierci właścicie- } \\
\text { la i odzyskania nieruchomości }\end{array}$ & $\begin{array}{l}\text { Przechodzi na fundusz hipoteczny } \\
\text { w momencie podpisania umowy, } \\
\text { osoba starsza może mieszkać do } \\
\text { śmierci, spadkobiercy nie mają } \\
\text { prawa do nieruchomości }\end{array}$ \\
\hline Podmiot oferujący & Banki i instytucje kredytowe & $\begin{array}{l}\text { Spółki prywatne - fundusze hipo- } \\
\text { teczne }\end{array}$ \\
\hline $\begin{array}{l}\text { Forma wypłaty środ- } \\
\text { ków }\end{array}$ & $\begin{array}{l}\text { Rata jednorazowa lub okreso- } \\
\text { wa, umowa na czas określony }\end{array}$ & $\begin{array}{l}\text { Renta wypłacana cyklicznie, doży- } \\
\text { wotnio }\end{array}$ \\
\hline Wiek beneficjenta & Bez ograniczeń & Minimum 60-65 lat \\
\hline $\begin{array}{l}\text { Utrzymanie nieru- } \\
\text { chomości }\end{array}$ & Po stronie kredytobiorcy & $\begin{array}{l}\text { Po stronie świadczeniodawcy, ale } \\
\text { istnieje możliwość przeniesienia na } \\
\text { klienta }\end{array}$ \\
\hline Spłata zadłużenia & $\begin{array}{l}\text { Po śmierci kredytobiorcy, } \\
\text { możliwa wcześniejsza spłata } \\
\text { kredytu }\end{array}$ & Nie występuje \\
\hline $\begin{array}{l}\text { Wycena nieruchomo- } \\
\text { ści objętej umową }\end{array}$ & $\begin{array}{l}\text { Przez niezależnego rzeczo- } \\
\text { znawcę }\end{array}$ & Przez spółkę \\
\hline $\begin{array}{l}\text { Możliwość rezygnacji } \\
\text { z usługi bez dodatko- } \\
\text { wych kosztów }\end{array}$ & 30 dni od podpisania umowy & Brak \\
\hline $\begin{array}{l}\text { Sprzedanie nierucho- } \\
\text { mości z beneficjen- } \\
\text { tem }\end{array}$ & Nie ma takiej możliwości & Możliwe \\
\hline $\begin{array}{l}\text { Wypłata niewykorzy- } \\
\text { stanej kwoty spadko- } \\
\text { biercom }\end{array}$ & Gwarantowana ustawą & Nie ma takiej możliwości \\
\hline $\begin{array}{l}\text { Zmiana wartości } \\
\text { nieruchomości }\end{array}$ & $\begin{array}{l}\text { Wzrost jest zyskiem dla kredy- } \\
\text { tobiorcy lub jego spadkobier- } \\
\text { ców, strata jest wpisana } \\
\text { w ryzyko kredytodawcy }\end{array}$ & $\begin{array}{l}\text { Korzyści i straty po stronie świad- } \\
\text { czeniodawcy }\end{array}$ \\
\hline Bezpieczeństwo & $\begin{array}{l}\text { Produkt regulowany ustawą - } \\
\text { ma być stworzony specjalny } \\
\text { Fundusz Gwarancyjny, nadzo- } \\
\text { rowany przez Komisję Nadzoru } \\
\text { Finansowego }\end{array}$ & $\begin{array}{l}\text { Produkt regulowany kodeksem } \\
\text { cywilnym, w razie bankructwa } \\
\text { dochodzenie praw na drodze sądo- } \\
\text { wej }\end{array}$ \\
\hline
\end{tabular}

Źródło: opracowanie na podstawie Marciniuk [2014: 257]; www8 [dostęp 28.12.2018]. 
Mimo że model kredytowy equity release w gruncie rzeczy polega na tym samym, co model sprzedażowy equity release, tj. przekształceniu kapitału zgromadzonego w nieruchomości w płynne środki finansowe [Kowalczyk-Rólczyńska 2017: 67], to istnieje wiele różnic pomiędzy funkcjonowaniem tych produktów finansowych. Wykaz podstawowych różnic pomiędzy odwróconym kredytem hipotecznym i świadczeniami dożywotnimi oferowanymi przez instytucje finansowe przedstawia Tabela 1 .

Powyższe informacje dotyczące świadczeń dożywotnich mają charakter poglądowy. Ostateczne warunki zależą od konkretnej umowy, czyli ustaleń między klientem a instytucją oferującą dany produkt. Przykładowo - wypłata środków może być nieregularna, a niewykorzystana kwota wypłacona spadkobiercom, wbrew temu co jest napisane w tab. 1.

\section{CHARAKTERYSTYKA UMÓW ŚWIADCZEŃ DOŻYWOTNICH}

W obecnym stanie prawnym na rynku polskim przedsiębiorcy oferujący świadczenia dożywotnie mogą stosować różnorodne rozwiązania, posługując się przepisami dotyczącymi [Raport z kontroli przedsiębiorców zawierających umowy świadczeń dożywotnich, 2013: 26]:

- umowy dożywocia,

- umowy renty,

- umowy ubezpieczenia,

- umowy pożyczki.

Podstawę prawną umowy dożywocia stanowi art. 908 § 1 k.c., w myśl którego ,jeżeli w zamian za przeniesienie własności nieruchomości nabywca zobowiązał się zapewnić zbywcy dożywotnie utrzymanie (umowa o dożywocie), powinien on, w braku odmiennej umowy, przyjąć zbywcę jako domownika, dostarczać mu wyżywienia, ubrania, mieszkania, światła i opału, zapewnić mu odpowiednią pomoc i pielęgnowanie $\mathrm{w}$ chorobie oraz sprawić mu własnym kosztem pogrzeb odpowiadający zwyczajom miejscowym" [Ustawa z dnia 23 kwietnia 1964 r. - Kodeks cywilny, Dz.U. 2018, poz. 1025 ze zm., art. 908 $\S 1]$. Definicja ta oznacza, że w zamian za przeniesienie własności nieruchomości zbywca określa czynności, które ma wykonywać na jego rzecz nabywca. Zwykle czynności te mają charakter osobisty i dotyczą zapewnienia kompleksowej opieki osobie starszej. Z tego względu stosowanie tej konstrukcji jest przewidziane w głównej mierze do regulowania stosunków rodzinnych [Durłak i Ciesek 2013: 290]. Niemniej jednak, umowa dożywocia znalazła także zastosowanie komercyjne. Jeżeli stroną umowy jest instytucja oferująca świadczenie dożywotnie, to przez „dożywotnie utrzymanie” najczęściej rozumie się zapewnienie beneficjentowi okresowych wypłat środków pieniężnych przy zachowa- 
niu możliwości zamieszkiwania lokalu [Lewicka 2015: 101-102]. W oparciu o te przepisy, umowy z seniorami zawierają m.in. Fundusz Hipoteczny DOM S.A., Fundusz Senior Sp. z o.o. i Fundusz Hipoteczny Omnes Sp. z o.o. Ostatni z wymienionych podmiotów proponuje seniorom następujące świadczenia $\mathrm{w}$ ramach umowy dożywocia [www5, dostęp 29.12.2018]:

- świadczenia pieniężne (np. na jego rzecz, na rzecz spadkobierców lub wierzycieli),

- świadczenia związane z mieszkaniem (np. przejęcie opłat za czynsz, prąd, media),

- świadczenia dotyczące opieki medycznej i zdrowia (np. zapewnienie ubezpieczenia zdrowotnego, prywatnej opieki pielęgniarskiej, opieki rehabilitacyjnej),

- świadczenia związane z potrzebami życia codziennego (szeroko pojęta pomoc osobistego asystenta przez kilka godzin w tygodniu),

- świadczenia pozostałe (np. zapewnienie kursu obsługi komputera, pomoc w przypadku awarii sprzętu elektronicznego, sprawienie pochówku).

Z kolei umowę renty określono w art. 903 k.c., który stanowi, że „przez umowę renty jedna ze stron zobowiązuje się względem drugiej do określonych świadczeń okresowych w pieniądzu lub w rzeczach oznaczonych tylko co do gatunku" [Ustawa z dnia 23 kwietnia 1964 r. - Kodeks cywilny, Dz.U. 2018, poz. 1025 ze zm., art. 903]. Jeżeli zapis ten wykorzystywany jest w przypadku komercyjnego oferowania świadczeń dożywotnich, to przez „określone świadczenia" zwykle rozumie się okresowe wypłaty pieniężne na rzecz beneficjenta oraz prawo zamieszkiwania przez niego nieruchomości. Renta może być ustanowiona za wynagrodzeniem bądź bez wynagrodzenia. Z uwagi na konieczność przeniesienia własności nieruchomości na przedsiębiorcę, zawierana umowa ma charakter renty za wynagrodzeniem, do której stosuje się przepisy o sprzedaży [Lewicka 2015: 102]. W oparciu o umowę renty świadczenia dożywotnie oferują m.in. Fundusz Hipoteczny DOM S.A. i Fundusz Hipoteczny Familia S.A.

W przypadku umowy ubezpieczenia podstawę prawną stanowi art. 805 $\S 1$ k.c., zgodnie z którym ,przez umowę ubezpieczenia ubezpieczyciel zobowiązuje się, w zakresie działalności swego przedsiębiorstwa, spełnić określone świadczenie $\mathrm{w}$ razie zajścia przewidzianego $\mathrm{w}$ umowie wypadku, a ubezpieczający zobowiązuje się zapłacić składkę" [Ustawa z dnia 23 kwietnia 1964 r. Kodeks cywilny, Dz.U. 2018, poz. 1025 ze zm., art. 805, § 1]. Taką konstrukcję prawną stosowało Towarzystwo Ubezpieczeń na Życie Europa. Od października 2013 r. produkt został jednak wycofany z oferty ubezpieczyciela, co było podyktowane tym, że prowadzone było przez Urząd Ochrony Konkurencji i Konsumentów (UOKiK) postępowanie administracyjne $\mathrm{w}$ sprawie stosowania przez Towarzystwo praktyk, które miały naruszać zbiorowe interesy konsumentów. $\mathrm{W}$ produkcie oferowanym przez ten podmiot odpowiednikiem składki, którą 
zobowiązany był uiścić ubezpieczający, była wartość lokalu, którego własność została przeniesiona na przedsiębiorstwo. Żeby klient nie stracił prawa do jego zamieszkiwania, ustanawiano służebność osobistą mieszkania (służebność osobista mieszkania polega na obciążeniu nieruchomości prawem na rzecz konkretnej osoby fizycznej, jest niezbywalna, wygasa najpóźniej ze śmiercią uprawnionego [Ustawa z dnia 23 kwietnia 1964 r. - Kodeks cywilny, Dz.U. 2018, poz. 1025 ze zm., art. 296, 299, 300]). W zamian ubezpieczyciel zobowiązywał się do wypłaty comiesięcznej renty na rzecz beneficjenta, a w razie jego śmierci - do dalszych wypłat na rzecz uposażonych (w przypadku, gdy śmierć nastąpiła wcześniej niż okres, jaki wskazano w umowie) [Lewicka 2015: 103].

Natomiast świadczenia dożywotnie skonstruowane o umowę pożyczki opierają się na art. $720 \S 1$ k.c., w myśl którego „przez umowę pożyczki dający pożyczkę zobowiązuje się przenieść na własność biorącego określoną ilość pieniędzy albo rzeczy oznaczonych tylko co do gatunku, a biorący zobowiązuje się zwrócić tę samą ilość pieniędzy albo tę samą ilość rzeczy tego samego gatunku i tej samej jakości" [Ustawa z dnia 23 kwietnia 1964 r. - Kodeks cywilny, Dz.U. 2018, poz. 1025 ze zm., art. 720 § 1]. Wobec tego przedsiębiorca pożycza osobie starszej środki pieniężne, które wypłaca w comiesięcznych ratach do dnia śmierci, ustalając hipotekę na posiadanej przez nią nieruchomości. Pożyczka może zostać umorzona w przypadku, gdy senior w testamencie wskaże przedsiębiorcę jako jedynego spadkobiercę. W przypadku tego typu umowy fundusz hipoteczny ma ograniczone możliwości, jeżeli chodzi o wpływ na stan lokalu i jego kontrolę. Przeniesienie własności nieruchomości następuje bowiem dopiero po śmierci konsumenta. $Z$ tego względu rozwiązanie to nie może być traktowane jako model sprzedażowy equity release [Lewicka 2015: 103]. Jedynym podmiotem, który oferował świadczenia dożywotnie w oparciu o umowę pożyczki, był Fundusz Senior Sp. z o.o. [Raport z kontroli przedsiębiorców zawierających umowy świadczeń dożywotnich, 2013: 37].

W powyższych rozważaniach zostały wymienione cztery podmioty oferujące aktualnie świadczenia dożywotnie, tj. Fundusz Hipoteczny DOM S.A., Fundusz Hipoteczny Familia S.A., Fundusz Senior Sp. z o.o., Fundusz Hipoteczny Omnes Sp. z o.o. Lista ta nie wyczerpuje wszystkich przedsiębiorców oferujących świadczenia dożywotnie w oparciu o model sprzedażowy equity release. Niemniej jednak, są to jedyne podmioty z branży, których propozycje ofertowe można szybko i bezproblemowo znaleźć za pośrednictwem Internetu.

\section{RYNEK ŚWIADCZEŃ DOŻYWOTNICH W POLSCE}

Z danych Ministerstwa Sprawiedliwości wynika, że w latach 1991-2017 zawarto w Polsce 132246 umów o dożywocie dotyczących nieruchomości. Umowy tego typu zyskują na popularności, czego potwierdzeniem jest fakt, że w $2008 \mathrm{r}$. 
podpisano ich 4 512, a w 2017 r. - 10395 [Akty Notarialne w latach 19912017, dostęp 08.01.2019]. Informacje na temat liczby zawieranych umów o dożywocie w poszczególnych latach zawiera wykres 1 .

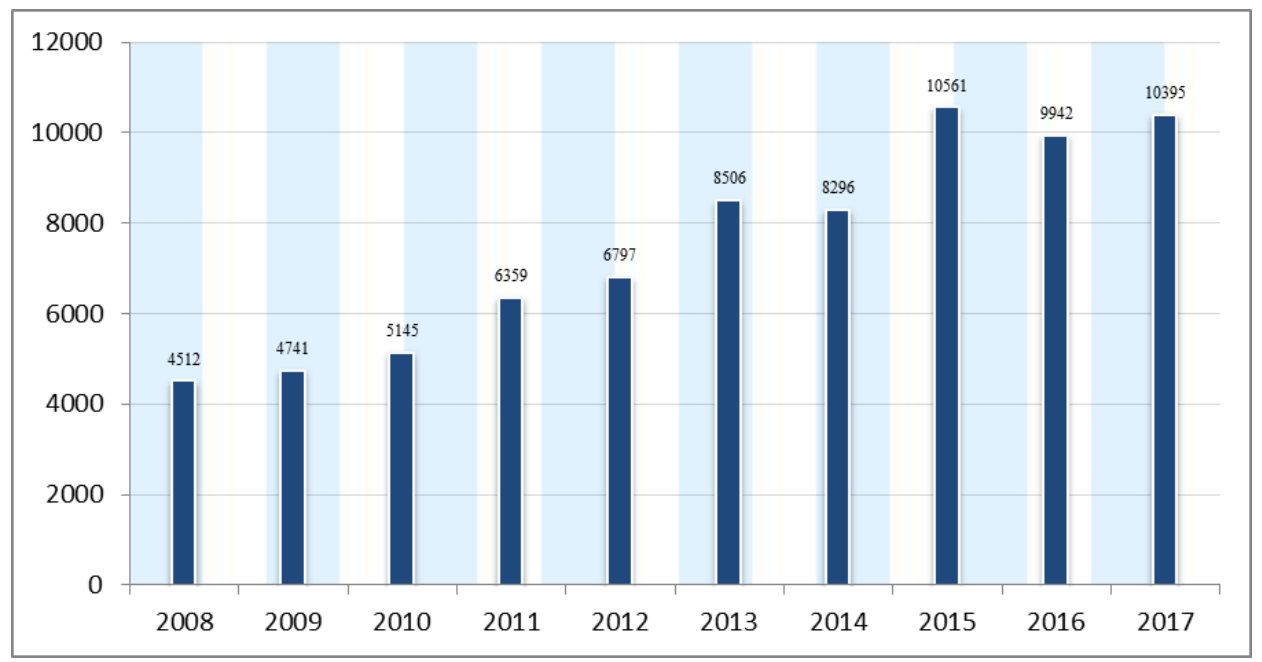

Wykres 1. Liczba podpisywanych umów dożywocia w Polsce w latach 2008-2017

Źródło: opracowanie na podstawie: Akty Notarialne w latach 1991-2017 [dostęp 08.01.2019].

W jednym z raportów o odwróconej hipotece w Polsce widnieje informacja, że ok. $99 \%$ z tych umów zawierana jest przez niewyspecjalizowane firmy i osoby fizyczne (krewnych, sąsiadów, znajomych, a nawet osoby obce) [Raport o hipotece odwróconej w Polsce..., 2018: 21]. Ten stan rzeczy może budzić pewne obawy, ponieważ podmioty te nie posiadają wiedzy i kapitału do prawidłowej wyceny, oceny ryzyka czy zagwarantowania spełnienia świadczeń w zawartych umowach [www3, dostęp 08.01.2019]. O skali problemu świadczy fakt, że w samym roku 2017 sądy unieważniły co piątą umowę dożywocia czyli ok. 2000 [Raport o hipotece odwróconej w Polsce..., 2018: 3]. Kwestia nadużyć, zarówno na profesjonalnym i nieprofesjonalnym rynku hipoteki odwróconej w Polsce, zostanie szerzej opisana w kolejnym rozdziale artykułu.

Zaopatrzone w odpowiedni kapitał, posiadające odpowiednią wiedzę, doświadczenie i od wielu lat regularnie wypłacające świadczenia polskim seniorom, są fundusze hipoteczne zrzeszone w Konferencji Przedsiębiorstw Finansowych (KPF). Podmioty te przestrzegają Zasad Dobrych Praktyk i poddają się corocznemu audytowi w tym zakresie [www3, dostęp 08.01.2019]. Należą do nich Fundusz Hipoteczny DOM S.A., istniejący od 2008 r. i Fundusz Hipoteczny Familia S.A., funkcjonujący od 2010 r. 
Charakteryzując produkty oferowane przez wyżej wymienione podmioty (tj. renty dożywotnie), warto wziąć pod uwagę następujące aspekty [Przewodnik po rencie dożywotniej, 2018: dostęp 10.01.2019; www7: dostęp 10.01.2019; www6: dostęp 10.01.2019]:

1. Rodzaj umowy. Zarówno Fundusz Hipoteczny Dom i Fundusz Hipoteczny Familia wypłacają świadczenia renty dożywotniej w oparciu o umowę renty (art. 903-907 k.c.). Dodatkowo Fundusz Hipoteczny DOM zawiera z klientami umowy o dożywocie (art. 908-916 k.c.).

2. Wiek świadczeniobiorcy. Fundusz Hipoteczny DOM kieruje swoją ofertę do osób, które ukończyły 60 lat i są właścicielami nieruchomości (domu lub mieszkania), podczas gdy z oferty Funduszu Hipotecznego Familia mogą skorzystać osoby, które ukończyły 65 . rok życia.

3. Terminy wypłat świadczenia. Fundusz Hipoteczny Dom i Fundusz Hipoteczny Familia wypłacają rentę dożywotnią co miesiąc, bez względu na to czy wartość wypłaconego świadczenia przekroczy wartość nieruchomości. Istnieje możliwość wypłaty jednorazowego świadczenia.

4. Wysokość renty dożywotniej. Wypłacana wysokość renty dożywotniej w Funduszu Hipotecznym Dom i Funduszu Hipotecznym Familia zależy w głównej mierze od wieku, płci oraz wartości nieruchomości. Kalkulacje są oparte m.in. o tablice dalszego trwania życia publikowane przez Główny Urząd Statystyczny, a wyceną wartości lokalu zajmuje się niezależny, licencjonowany rzeczoznawca majątkowy. Fundusz Hipoteczny DOM waloryzuje świadczenie co kwartał o wskaźnik zmian ceny towarów i usług, natomiast Fundusz Hipoteczny Familia waloryzacji dokonuje raz w roku w oparciu o podobny wskaźnik dla gospodarstw domowych emerytów i rencistów.

5. Zabezpieczenia roszczeń klientów. Fundusz Hipoteczny DOM i Fundusz Hipoteczny Familia dokonują wpisu w księdze wieczystej o dożywotnim prawie użytkowania nieruchomości przez klienta, ustanawiają na rzecz klienta hipotekę umowną do kwoty odpowiadającej wartości nieruchomości (dzięki której możliwe jest odzyskanie należnej renty bądź prawa własności do mieszkania w razie, gdyby spółka nie wywiązywała się z warunków umowy lub nastąpiła jej upadłość), składają oświadczenie o poddaniu się egzekucji w trybie art. 777 Kodeksu postepowania cywilnego (który zapewnia błyskawiczną egzekucję u komornika należności w sytuacji zalegania przez spółkę z wypłatą nawet jednomiesięcznej renty).

6. Strona ponosząca koszty. Fundusz Hipoteczny DOM i Fundusz Hipoteczny Familia pokrywają wszystkie koszty zawarcia umowy, takie jak wycena nieruchomości, notariusz. Ponadto, spółki te opłacają podatek od nieruchomości, wnoszą opłaty z tytułu użytkowania wieczystego oraz ubezpieczenia nieruchomości od ognia, powodzi i innych zdarzeń losowych. Czynsz obciąża pobierającego świadczenie, ale oba fundusze hipoteczne potrącają odpowiednie kwoty 
z wypłacanej renty i przekazują je bezpośrednio do zarządcy. Senior musi we własnym zakresie dokonywać drobnych napraw wynikających ze zwykłego korzystania $\mathrm{z}$ lokalu, a także regulować opłaty związane $\mathrm{z}$ dostarczanymi mediami i usługami.

7. Najem nieruchomości. Po uzyskaniu zgody od spółki (Funduszu Hipotecznego DOM, Funduszu Hipotecznego Familia) klient może wynajmować mieszkanie i pobierać z tego tytułu korzyści finansowe.

8. Dodatkowe korzyści. Fundusz Hipoteczny DOM zapewnia klientom uczestnictwo w Klubie Seniora DOM, dostęp do Srebrnej Linii (serwis awaryjny, serwis informacyjny, porady prawne), darmową prenumeratę czasopisma „Życie Seniora”. Fundusz Hipoteczny Familia zapewnia klientom bezpłatny pakiet opiekuńczy Assistance oraz pakiet porad prawnych.

9. Procedura zawierania umowy. W Funduszu Hipotecznym DOM i Funduszu Hipotecznym Familia wygląda ona podobnie i obejmuje następujące etapy: spotkanie $\mathrm{z}$ doradcą, przedstawienie oferty i warunków umowy, prognoza renty dożywotniej, wycena nieruchomości przez rzeczoznawcę, przekazanie klientowi raportu i operatu szacunkowego, zawarcie umowy renty dożywotniej w formie aktu notarialnego.

Sytuację na polskim rynku świadczeń dożywotnich oferowanych w latach 2010-2017 przez fundusze hipoteczne zrzeszone w KPF przedstawia Tabela 2.

Do 2014 roku można było obserwować dynamiczny wzrost aktywnych umów - z 13 na koniec roku 2010 do 302 w roku 2014. Największy, bezwzględny wzrost odnotowano w roku 2012, na koniec którego liczba umów była wyższa o 103 szt. w stosunku do końca roku 2011. Od roku 2014 nastąpiła stagnacja i nieznaczny spadek do 294 aktywnych umów na koniec roku 2016 i 2017.

Średni wiek klientów, czyli uśredniona liczba lat na moment podpisywania umowy, oscylował $\mathrm{w}$ analizowanym okresie $\mathrm{w}$ przedziale pomiędzy około 75 a 79 lat. Początkowo zauważalny był spadek średniego wieku klientów, z 76,7 lat w roku 2010 do 74,9 w roku 2013. W kolejnych latach odnotowano spory wzrost, do poziomu 79,4 lat w roku 2016. Na koniec roku 2017 średni wiek klientów nieco się obniżył do 78,9 lat.

Od 2011 roku średni metraż mieszkania na koniec kolejnych lat systematycznie rośnie. W 2011 roku było to $42,3 \mathrm{~m}^{2}$, podczas gdy dla roku 2017 $49,1 \mathrm{~m}^{2}$. Największy przyrost względem poprzedniego roku odnotowano $\mathrm{w}$ roku 2012 - średni metraż wyniósł wówczas $46,3 \mathrm{~m}^{2}$ (tj. o $4 \mathrm{~m}^{2}$ więcej niż w 2011).

Średnia wartość jednej zarządzanej nieruchomości do końca 2014 roku znajdowała się w trendzie spadkowym, od 321,5 tys. PLN w 2010 roku do 237,1 tys. PLN w roku 2014. Po tym okresie zauważa się wzrost tej wartości, do poziomu 255,1 tys. PLN na koniec roku 2017. 
Tabela 2. Sytuacja na polskim rynku świadczeń dożywotnich oferowanych w latach 2010-2017 przez fundusze hipoteczne zrzeszone w KPF

\begin{tabular}{|l|c|c|c|c|c|c|c|c|}
\hline Lata & 2010 & 2011 & 2012 & 2013 & 2014 & 2015 & 2016 & 2017 \\
\hline $\begin{array}{l}\text { Liczba aktywnych umów } \\
\text { (w szt.) }\end{array}$ & 13 & 96 & 199 & 278 & 302 & 303 & 294 & 294 \\
\hline $\begin{array}{l}\text { Średni wiek klienta } \\
\text { (w latach) }\end{array}$ & 76,7 & 75,1 & 75,5 & 74,9 & 78,5 & 79,0 & 79,4 & 78,9 \\
\hline $\begin{array}{l}\text { Średni metraż mieszkania } \\
\text { (w m) }\end{array}$ & 43,3 & 42,3 & 46,3 & 47,1 & 47,3 & 47,7 & 48,4 & 49,1 \\
\hline $\begin{array}{l}\text { Średnia wartość jednej } \\
\text { nieruchomości (w tys. PLN) }\end{array}$ & 321,5 & 251,3 & 253,1 & 243,1 & 237,1 & 247,1 & 254,2 & 255,1 \\
\hline $\begin{array}{l}\text { Wartość zarządzanych } \\
\text { nieruchomości (w mln PLN) }\end{array}$ & 4,2 & 24,1 & 50,4 & 67,6 & 71,6 & 74,9 & 74,7 & 75,0 \\
\hline $\begin{array}{l}\text { Lączna wypłacona renta - } \\
\text { wartości roczne (w mln } \\
\text { PLN) }\end{array}$ & - & 1,14 & 1,40 & 2,50 & 2,96 & 2,79 & 2,48 & 2,59 \\
\hline $\begin{array}{l}\text { Lączna wypłacona renta - } \\
\text { wartości skumulowane } \\
\text { (w mln PLN) }\end{array}$ & 0,11 & 1,25 & 2,66 & 5,15 & 8,11 & 10,90 & 13,39 & 15,98 \\
\hline
\end{tabular}

Źródło: opracowanie na podstawie: Rynek odwróconej hipoteki w modelu sprzedażowym..., [2018: 7-10].

Od roku 2010 do roku 2013 zauważalny był dość dynamiczny wzrost, jeśli chodzi o łączną wartość zarządzanych nieruchomości - z 4,2 mln PLN do 67,6. W następnych dwóch latach wartość ta rosła znacznie wolniej, a od roku 2015 oscyluje na względnie stałym poziomie. Na koniec roku 2017 wartość zarządzanych nieruchomości wyniosła $75 \mathrm{mln}$ PLN.

W latach 2010-2017 fundusze hipoteczne wypłaciły klientom niespełna 16 mln PLN. W roku 2017 wypłacono 2,59 mln PLN, co stanowi wartość wyższą niż w roku 2016 (2,48 mln PLN). Najwięcej wypłacono w roku 2014 2,96 mln PLN. Co warte dodania, w latach 2011 i 2012 wartość roczna wypłaconej renty była sporo niższa od tych w kolejnych latach i nie przekroczyła poziomu 1,4 mln PLN.

Najwięcej nieruchomości zarządzanych przez fundusze hipoteczne na koniec roku 2017 znajdowało się w województwie mazowieckim - 33\%. Drugimi w kolejności są województwa pomorskie i dolnośląskie, w których na koniec roku 2017 znajdowało się po 12,2\% administrowanych nieruchomości, natomiast nieco mniej, 10,9\%, położone było w województwie śląskim. W pozostałych województwach odsetek był znacznie niższy i wynosił od 0,7\% (województwa podlaskie i podkarpackie) do 5,4\% (województwo wielkopolskie). Wzrost 
udziału administrowanych umów względem końca 2016 roku odnotowano w województwach mazowieckim, zachodnio-pomorskim, kujawsko-pomorskim i warmińsko-mazurskim. Największy wzrost zaobserwowano w województwie mazowieckim - o 1,7 p.p. [Rynek odwróconej hipoteki w modelu sprzedażowym..., 2018: 11].

Udział nieruchomości w poszczególnych województwach w łącznej liczbie zarządzanych nieruchomości w 2017 r., oraz zmianę w p.p. względem 2016 r., przedstawia rys. 1 .

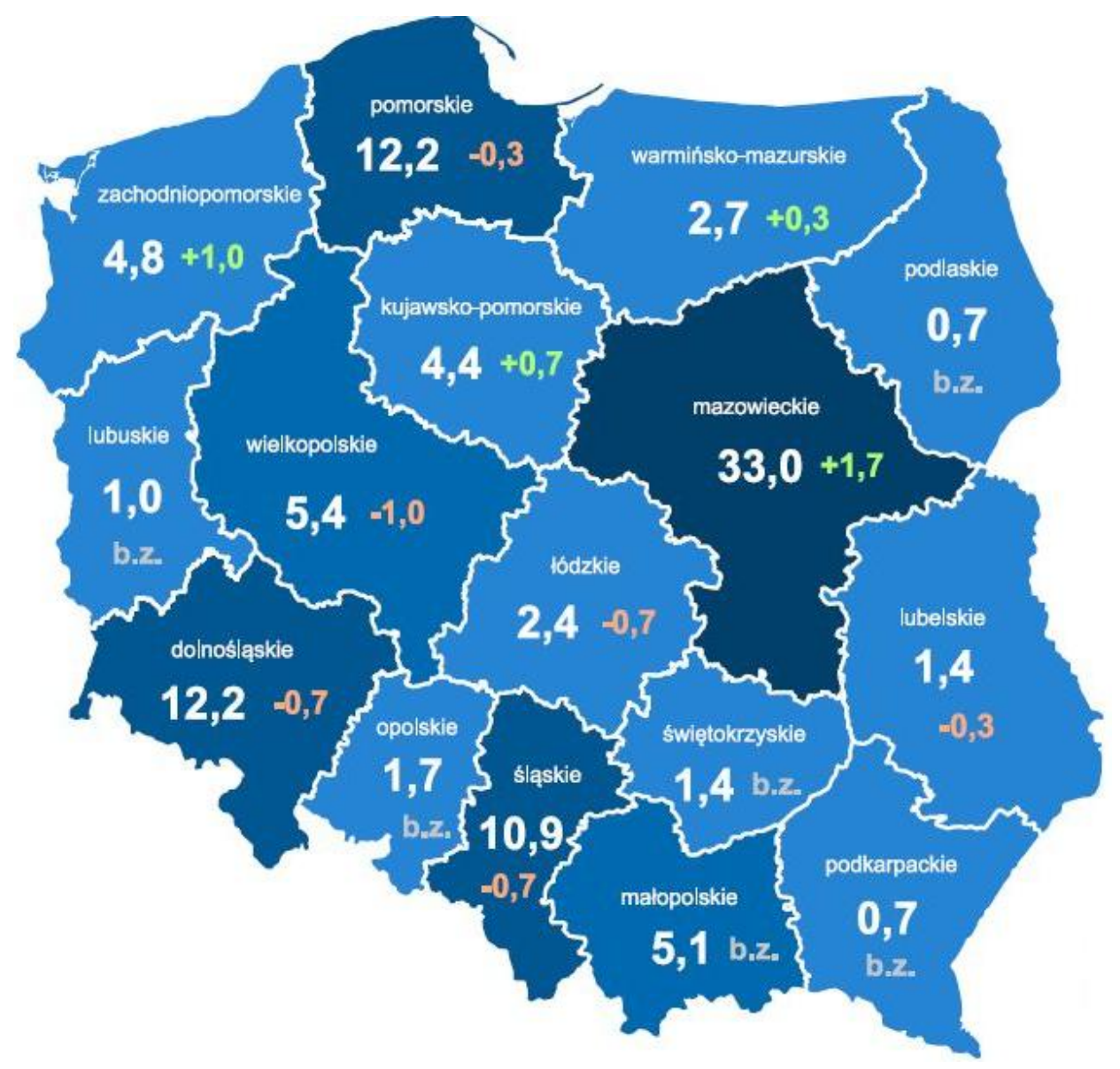

Rysunek 1. Udział nieruchomości w poszczególnych województwach w łącznej liczbie zarządzanych nieruchomości w 2017 r. oraz zmiana w p.p. względem 2016 r.

Źródło: Rynek odwróconej hipoteki w modelu sprzedażowym..., [2018: 11]. 


\section{NARUSZENIA ZWIAZZANE Z UMOWAMI ŚWIADCZEŃ DOŻYWOTNICH}

Komisja Nadzoru Finansowego nie nadzoruje instytucji oferujących usługi equity release $\mathrm{w}$ modelu sprzedażowym. Nie jest też konieczne zezwolenie KNF na rozpoczęcie działalności. KNF nie jest upoważniona do przeprowadzania inspekcji i wydawania zaleceń takim podmiotom. Ponadto, instytucje oferujące usługi equity release w modelu sprzedażowym nie mają narzuconych żadnych wymogów odnośnie wypłacalności, nie są zobligowane do utrzymania jakiejkolwiek płynności finansowej. Aktualnie jedynie Prezes Urzędu Ochrony Konkurencji i Konsumentów może kontrolować np. wzorce umowne i przestrzeganie przed przedsiębiorców przepisów ustaw. Nie robi tego jednak w sposób ciągły, co oznacza, że podejmuje działania dopiero wtedy, gdy do urzędu dochodzą sygnały o jakichś nieprawidłowościach [Dankowska i Fielek 2018: 134-136].

Przykładem działania Prezesa UOKiK jest wystąpienie z powództwem przeciwko Funduszowi Hipotecznemu DOM S.A. za praktyki naruszające zbiorowe interesy konsumentów, a dokładnie kwestię reklamy, w której podano, że renta hipoteczna to produkt o charakterze państwowym, podczas gdy w rzeczywistości było to świadczenie o charakterze typowo komercyjnym [Decyzja Prezesa UOKiK, numer decyzji: RWA-12/2012: 1, 8]. Innym przykładem działania Prezesa UOKiK jest to, że w 2013 r. poddał kontroli przedsiębiorców zawierających profesjonalne umowy świadczeń dożywotnich (tj. Towarzystwo Ubezpieczeń na Życie Europa S.A., Fundusz Hipoteczny Dom S.A., Fundusz Hipoteczny Gwarancja Sp. z o.o., Fundusz Senior Sp. z o.o., Fundusz Hipoteczny Familia S.A., Fundusz Hipoteczny Omnes Sp. z o.o.). Z raportu wynika, że zbadano w sumie 37 wzorców umownych, z czego zakwestionowano 17, stwierdzając 29 nieprawidłowości. Dotyczyły one np.: uzależnienia od decyzji spółki możliwości przyjęcia do mieszkania osób spokrewnionych, ponoszenia przez konsumenta nadmiernych kosztów dotyczących utrzymania nieruchomości oraz nakładania na spadkobierców trudnych do spełnienia obowiązków [Paduszyńska i Zbyszewski 2016: 30]. Zdaniem autorów raportu zakres i charakter tych naruszeń nie przekłada się w sposób bezpośredni na jakość wykonywanych świadczeń, ponieważ losowo ankietowani konsumenci wyrażali zadowolenie z podpisanych umów, oznajmiając, że pieniądze są wypłacane terminowo, a fundusze hipoteczne utrzymują z nimi kontakt i interesują się ich losem [Raport z kontroli przedsiębiorców zawierających umowy świadczeń dożywotnich, 2013: 83-84].

Ewidentne naruszenia związane $\mathrm{z}$ umowami świadczeń dożywotnich mają miejsce w głównej mierze na rynku nieprofesjonalnym, tzn. wtedy, gdy świadczeniodawcą jest niewyspecjalizowana firma bądź osoba fizyczna. Na przestrzeni ostatnich lat w mediach pojawił się ogrom informacji o oszustwach wobec osób starszych, od których wyłudzane są mieszkania m.in. pod pretekstem ,po- 
życzki pod zastaw nieruchomości”, „hipoteki odwróconej” bądź „renty hipotecznej" [Raport o hipotece odwróconej w Polsce..., 2018: 6]. Oto kilka wybranych przykładów nadużyć [Raport o hipotece odwróconej w Polsce..., 2018: 13-14]:

1. Pani Lidia z Sopotu (88 lat). Oszukana przez zaprzyjaźnionego księdza. W akcie notarialnym duchowny zobowiązywał się do opłacania rachunków, zapewnienia niezbędnej opieki, zakupu jedzenia, leków, ubrań i opału. Ze świadczeń się nie wywiązał, a gdy Pani Lidia zwróciła się do niego z pismem o zwrot nieruchomości, lokal przeszedł w ręce brata księdza. Sprawą zajęła się prokuratura.

2. Państwo Listopadzcy (77 lat). Wpadli w długi i żeby ratować swój dobytek przepisali dom wraz z zabudowaniami na siostrzeńca, który zobowiązał się do dożywotniej opieki nad nimi. Po kilku latach krewny przestał ich odwiedzać, a ostatecznie sprzedał nieruchomość. Nowy właściciel, na którego przeszedł obowiązek opieki, zaproponował Państwu Listopadzkim jedynie 526 zł/msc. Sprawa swój finał będzie mieć w Sądzie Najwyższym.

3. Pani Janina z Gdańska. W zamian za 21 tysięcy pożyczki oddała dwupokojowe mieszkanie przy gdańskiej Zaspie, które zamieszkiwała wraz z synami. Ponieważ pożyczki nie zdołała spłacić, mieszkanie przeszło na nowego właściciela, który pod jej nieobecność wymienił zamki w drzwiach.

4. Pani Helena z Opola (96 lat). Przekazała za bezcen swoje mieszkanie w centrum miasta rehabilitantowi, który w zamian miał się nią zajmować. Zamiast tego zaczął ją nękać i nachodzić. Sprawa trafiła do sądu.

5. Państwo Ibiszowie z Lublina. Ich mieszkanie padło łupem oszusta, który w zamian za pomoc w spłacie kredytu w banku miał stać się jego właścicielem po śmierci Państwa Ibiszów. Niestety pozbawił ich dachu nad głową znacznie wcześniej.

Sytuacji, takich jak powyżej opisane, występuje całe mnóstwo. Bierze się to m.in. $\mathrm{z}$ tego, że osoby starsze są jedną z grup społecznych najbardziej narażonych na ryzyko oszustwa. $Z$ danych Biura Informacji Kredytowej wynika, iż spośród osób w wieku 65 lat i więcej, aż $10 \%$ było ofiarą próby wyłudzenia pieniędzy przez oszustów. Jak podaje Policja, przestępcy każdego dnia (minimum 5 razy dziennie) dokonują prób oszukania osoby starszej [www4: dostęp 30.01.2019].

$\mathrm{Z}$ uwagi na liczne naruszenia, nadużycia, oszustwa rynek equity release w modelu sprzedażowym powinien zostać jak najszybciej uregulowany. O stworzenie odpowiednich przepisów, które gwarantowałyby seniorom należyte bezpieczeństwo, od 2013 r. postulują m.in. Urząd Ochrony Konkurencji i Konsumentów, Rzecznik Praw Obywatelskich i fundusze hipoteczne zrzeszone w Konferencji Przedsiębiorstw Finansowych. Według tych podmiotów należy przede wszystkim podjąć działania zmierzające do profesjonalizacji usługi [Rynek od- 
wróconej hipoteki w modelu sprzedażowym..., 2018: 4]. Obecne rozwiązania prawne nie są wystarczające dla uregulowania w sposób bezpieczny relacji senior - instytucja finansowa, zostały bowiem stworzone na potrzeby stosunków rodzinnych bądź bliskich stosunków społecznych. W kodeksie cywilnym brakuje choćby szczegółowych regulacji w zakresie obowiązków przedkontraktowych [Dankowska i Fielek 2018: 135]. Wydaje się, że oprócz stworzenia przepisów regulujących rynek powinno się także zadbać o zapewnienie seniorom dostępu do profesjonalnego doradztwa i informacji, stworzenie norm etycznych obowiązujących w branży i zainicjowanie kampanii edukacyjnych skierowanych do osób starszych [Raport o hipotece odwróconej w Polsce..., 2018: 11].

Do tej pory najbliżej do uregulowania rynku equity release $\mathrm{w}$ modelu sprzedażowym było w 2014 r. Wówczas Ministerstwo Gospodarki dysponowało gotowym projektem Ustawy o dożywotnim świadczeniu pieniężnym. Projekt ten przewidywał, iż właściciel mieszkania, domu jednorodzinnego bądź posiadacz spółdzielczego własnościowego prawa do lokalu mógłby podpisać umowę o dożywotnie świadczenie pieniężne. W zamian za prawo własności nieruchomości świadczenia takie wypłacać mogłyby spółki akcyjne posiadające zezwolenie KNF na prowadzenie takiej działalności. Minimalny kapitał zakładowy takiego podmiotu wynosić miał $2 \mathrm{mln}$ euro. Po zawarciu umowy $\mathrm{w}$ formie aktu notarialnego przenoszącej prawo własności w zamian za dożywotnie świadczenie (waloryzowane co roku o wskaźnik inflacji) dawny właściciel w dalszym ciągu zamieszkiwałby lokum, a zapewniałaby mu to służebność osobista ustanowiona na jego rzecz. Dożywotnią wypłatę świadczeń gwarantowałaby natomiast obciążająca nieruchomość hipoteka w wysokości co najmniej $150 \%$ jej wartości rynkowej. Ostatecznie projekt został wycofany z prac legislacyjnych. Przyczyną tego stanu rzeczy był fakt, że resortem gospodarki kierował wtedy Janusz Piechociński z Polskiego Stronnictwa Ludowego, podczas gdy Sejm pod koniec kadencji realizował wyłącznie projekty firmowane przez Platformę Obywatelską. Animuszu zabrakło również z tego powodu, że jednocześnie $w$ resorcie finansów trwały prace nad ostatecznie uchwaloną Ustawą o odwróconym kredycie hipotecznym [www2: dostęp 30.01.2019]. Istnieje szansa, że w najbliższej przyszłości rynek equity release w modelu sprzedażowym doczeka się w końcu regulacji. Dokument przedstawiający założenia polityki społecznej wobec osób starszych do 2030 roku zaktualizowano bowiem o punkt dotyczący opracowania projektu ustawy o rencie dożywotniej, a propozycja została uwzględniona przez Stały Komitet Rady Ministrów [www1: dostęp 30.01.2019]. 


\section{PODSUMOWANIE}

Equity release w modelu sprzedażowym polega na tym, że właściciel nieruchomości przenosi na świadczeniodawcę prawo własności do całości lub części nieruchomości w zamian za wypłatę ustalonych świadczeń pieniężnych (zazwyczaj realizowanych dożywotnio) oraz możliwość zamieszkiwania w tej nieruchomości do śmierci.

$Z$ racji tego, że brakuje uregulowań prawnych, rozwiązania wykorzystywane w modelu sprzedażowym obecnie oparte są na przepisach kodeksu cywilnego (czyli umowy dożywocia, umowy renty, umowy ubezpieczenia, umowy pożyczki). Szacuje się, że ok. 99\% umów tego typu zawierane jest przez niewyspecjalizowane firmy i osoby fizyczne, nie posiadające wiedzy i kapitału do rzetelnej wyceny, oceny ryzyka i zagwarantowania spełnienia świadczeń w zawartych umowach. Ten stan rzeczy prowadzi do licznych naruszeń, nadużyć, oszustw na rynku equity release w modelu sprzedażowym. Tym samym autor artykułu znajduje odpowiedź na swoje pytanie badawcze: niezbędne jest stworzenie odpowiednich przepisów, które zapewniałaby seniorom należyte bezpieczeństwo. O tym, że uregulowanie rynku jest potrzebne świadczy fakt, że od kilku lat postulują o to Urząd Ochrony Konkurencji i Konsumentów, Rzecznik Praw Obywatelskich oraz fundusze hipoteczne zrzeszone w Konferencji Przedsiębiorstw Finansowych (tj. Fundusz Hipoteczny DOM S.A. i Fundusz Hipoteczny Familia S.A.).

Wydaje się, że w niedalekiej przyszłości rynek equity release $\mathrm{w}$ modelu sprzedażowym doczeka się regulacji. Można ten wniosek wysnuć na podstawie tego, że dokument opisujący założenia polityki społecznej wobec osób starszych do 2030 roku uzupełniono o punkt dotyczący opracowania projektu ustawy o rencie dożywotniej. Do rozwoju equity release w modelowym sprzedażowym poza stworzeniem przepisów regulujących rynek potrzebne są także inne działania. Powinno się zadbać m.in. o zapewnienie osobom starszym dostępu do profesjonalnego doradztwa i informacji, stworzenie norm etycznych obowiązujących w branży i zainicjowanie kampanii edukacyjnych skierowanych do seniorów.

\section{BIBLIOGRAFIA}

Akty Notarialne w latach 1991-2017, Ministerstwo Sprawiedliwości, https://dane.gov.pl/data set/1209 [dostęp 08.01.2019].

Dankowska A., Fielek A., 2018, Ochrona konsumentów ustug equity release, [w:] M. Cycoń, T. Jedynak, G. Strupczewski (red.), Nowe trendy w zabezpieczeniu emerytalnym w Polsce. Przegląd Ubezpieczeń 2018, Fundacja Uniwersytetu Ekonomicznego w Krakowie, Kraków.

Decyzja Prezesa UOKiK, numer decyzji: RWA-12/2012, data decyzji: 2012-07-31, Warszawa. 
Durłak A., Ciesek Ł., 2013, Zagrożenia zwiazane z funkcjonowaniem rent dożywotnich $w$ Polsce, [w:] W. Sułkowska (red.), Rynek ubezpieczeń. Wspótczesne problemy, Difin, Warszawa.

Kowalczyk-Rólczyńska P., 2017, Equity release - ryzyko i jego determinanty, [w:] E. RutkowskaTomaszewska (red.), „Odwrócona hipoteka” jako nowa ustuga na rynku finansowym, C.H.Beck, Warszawa 2017.

Lewicka B., 2015 Rynek świadczeń dożywotnich w Polsce, [w:] T. H. Bednarczyk (red.), Ubezpieczenia $i$ bankowość z perspektywy młodego ekonomisty. Wybrane problemy, Uniwersytet Marii Curie-Skłodowskiej, Lublin.

Marciniuk A., 2014, Renta hipoteczna a odwrócony kredyt hipoteczny na rynku polskim, „Śląski Przegląd Statystyczny", nr 12(18).

Paduszyńska M., Zbyszewski S., 2016, Istota i znaczenie odwróconej hipoteki w obliczu starzenia się spoteczeństwa polskiego, „Finanse i Prawo Finansowe”, t. III, nr 2.

Przewodnik po rencie dożywotniej, 2018, Fundusz Hipoteczny DOM, Warszawa, https://www.funduszhipoteczny.pl/wp-content/uploads/2018/12/Przewodnik-po-renciedo\%C5\%BCywotniej_gru2018.pdf [dostęp 10.01.2019].

Raport o hipotece odwróconej w Polsce. Wyzwania, zagrożenia, potencjał rynku, 2018, Konferencja Przedsiębiorstw Finansowych w Polsce i Fundusz Hipoteczny DOM, Warszawa.

Raport z kontroli przedsiębiorców zawierających umowy świadczeń dożywotnich, 2013, UOKiK, Wrocław.

Rynek odwróconej hipoteki w modelu sprzedażowym. Lata 2010-2017, 2018, KPF, Gdańsk.

Ustawa z dnia 23 kwietnia 1964 r. - Kodeks cywilny, Dz.U. 2018, poz. 1025 ze zm.

Willmann M., 2016, Odwrócony kredyt hipoteczny jako źródło uposażenia emerytalnego, „Prace Naukowe Uniwersytetu Ekonomicznego we Wrocławiu", nr 426.

[www1] https://alebank.pl/odwrocona-hipoteka-co-dalej/ [dostęp 30.01.2019].

[www2] https://finanse.gazetaprawna.pl/artykuly/1356175,reaktywacja-renty-hipotecznej.html [dostęp 30.01.2019].

[www3] https://kpf.pl/rynek-hipoteki-odwroconej-w-2017-roku/ [dostęp 08.01.2019].

[www4] https://media.bik.pl/informacje-prasowe/381751/ponad-pol-miliona-prob-wyludzen-naosobach-starszych [dostęp 30.01.2019].

[www5] http://omnes.com.p1/?oferta-korzysci [dostęp 29.12.2018].

[www6] https://www.bankier.pl/wiadomosc/Mieszkanie-za-dodatek-do-emerytury-jak-dzialarenta-dozywotnia-7568230.html [dostęp 10.01.2019].

[www7] http://www.familiasa.pl/czeste-pytania [dostęp 10.01.2019].

[www8] https://www.money.pl/gospodarka/raporty/artykul/odwrocona-hipoteka-to-martweprawo-zaden,248,0,1676024.html [dostęp 28.12.2018].

\section{FUNCTIONING OF THE SALE MODEL EQUITY RELEASE IN POLAND}

\section{Abstract}

The aim of the article is to present the fuctioning of the sale model equity release in Poland. While analyzing lifetime benefits concluded with elderly people the autor noticed that the market of sale model equity release in Poland needs new legal regulations. Current law regulations are not enough to protect the interest of elderly people.

Keywords: lifetime benefits, lifetime pension, life contract, reverse mortgage, mortgage funds. 